\title{
The Japanese Corporate Sports System: a Unique Style of Sports Promotion
}

\author{
Katrin Jumiko Leitner
}

\begin{abstract}
While the organisation of sports in different countries is structured primarily on regional sports clubs, sports in Japan are based to a large extent on corporate sports. In corporate sports, Japanese companies are the owners of sports teams and their members must be employees of the company, meaning that the athletes work in addition to their sporting activities.

This article deals with the system of corporate sports, using the example of corporate judo teams. First, the author gives a detailed description of the corporate judo teams to show how the system works. The question is then posed why the corporate sports system still exists in judo while a large number of teams in many other sports have broken up since the 1990s, and the breakdown of the corporate sports system will be analysed.

Reasons for the preservation of the corporate sports system in judo were found in business relations, in the marketing of sports, in the organisation of sports in Japan and in the special importance of judo in that country. However, although the corporate sports system has been maintained in Japanese judo up to the present day, a trend towards a modern form of corporate sports can be seen.
\end{abstract}

Keywords: amateur, competitive sports, judo, professionalism, semi-professional, sponsorship, sports promotion Sports Promotion." In Vienna Graduate Journal of East Asian Studies, Volume 2, eds. Rudiger Frank, Ingrid Getreuer-Kargl, Lukas Pokorny and Agnes Schick-Chen. Vienna: Praesens Verlag, 2011, pp. 27-54. https://doi.org/10.2478/vjeas-2011-0008 


\title{
Introduction
}

\begin{abstract}
Athletes who have excelled in a sport in high school and university are recruited by a company, and though hired as ordinary employees, their jobs are not in production or sales but as members of the company team. Companies maintain sports facilities and training camps and pay most of the expenses for their athletes. They also organize attendance at events and support for their teams (Ohno 2002: 23).
\end{abstract}

This brief description gives an outline of how the Japanese corporate sports system works. This kind of sports promotion is pretty well unique when compared to other sporting systems all over the world. In the United States as well as in Europe, there are no sports teams that are part of a company. They are mostly associated with a regional area. Inhabitants of a city and the nearby region can become members of any sports club within the area and are allowed to use the club's sporting facilities. Moreover, there are mostly no limitations to joining a club, which means that men and women, regardless of their age, practice side by side in the same club. This kind of sports club or way of organising sports is the most common form of sporting practice all over the world (Tamaki 2006: 102-103). In Japan, however, the sports system is not based on regional clubs, but primarily on school sports as well as on sports at university, and secondly on the corporate sports system.

The first contact I had with the Japanese corporate sports system was while I was staying at a judo training camp in Japan. Our team was allowed to take part in the practice sessions of the Women's Judo Team of Komatsu コマツ (a company producing construction machinery). At first I only knew that all members of the judo team were ordinary employees of Komatsu. However, as I stayed on, I found out that most of them worked merely a few days a week and that some of them did not work at all. Some only practised judo. Moreover, nearly all the athletes were members of the Japanese national team or at least had the prospect of being called up in the near future. I figured out that all of them entered this company because of their excellent sporting results and that they received considerable support from the company concerning their sporting activities. As I mentioned before, regional sports clubs are generally the norm in Europe, and activities in competitive sports as well as in mass sports are based on them. In almost all cases of regional clubs, companies act as sponsors to foster their sporting activities and expect some benefit in advertising for themselves in return. However, before getting to know the Japanese corporate sports system, I had never heard of a company owning a sports team, composed of the company's employees only.

In this article I will deal with the Japanese corporate sports system, using the example of corporate judo teams. I decided to base this work on two major issues. The reason for these two questions is that along with a substantial analysis of the current problems of the corporate sports system, I found it very important to describe the system itself in detail. Research on this subject is still insufficient outside of Japan; 
in particular, detailed descriptions of the system are not available, even inside Japan. Hence, this work should provide an insight into the Japanese corporate sports system, because I believe that this kind of sports promotion could also be applied successfully in other countries. Especially in Austria, I feel a lack of institutions for promoting athletes, mainly within individual minor sports, who aspire to become the top in their sports. It is up to the Austrian army to foster individual athletes by guaranteeing them a stable livelihood so that they can concentrate on their sports alone. Companies employing athletes and promoting their sporting activities might prove to be additional institutions for bringing up athletes in competitive sports as well as offering them employment at the same time. This is a matter that should merit serious consideration. The advantage of corporate sports is the possibility to combine competitive sports with work or at least with vocational training. Through the description of the Japanese corporate sports system in this article I will try to indicate the existence of such a special form of sports promotion.

The essay starts with a brief outline of the history of Japanese corporate sports in general, in which not only judo but also different kinds of sports, especially those that have had a great impact on the development of the corporate sports system, will be illustrated. Thereafter I will examine how the system is constructed in detail and which characteristics and particularities are in evidence. I will describe the system on the particular basis of the corporate judo teams. The main points will be entry and recruitment into the company, the management of work and training time, the system of wages and bonuses for the athletes, and job prospects after the end of the athletes' sporting career.

The section on 'The break-up of the Japanese corporate sports system' refers to the problems in Japanese corporate sports, with the frequent breaking up of corporate teams from the 1990 s to the present. As a result, the whole system has been put at risk of collapsing entirely. In contrast, corporate judo was obviously spared from such break-up, as to my knowledge there have been almost no closings of corporate judo teams. Moreover, corporate athletes are still dominant at the top level of Japanese judo, which has also been proved in the number of corporate athletes who have competed successfully in the Olympic Games or World Championships over the past years. I want to find out what the reasons are for the preservation of the corporate sports system in Japanese judo. In the section discussing 'Prerequisites for the preservation of corporate judo teams', I seek to examine if judo in Japan has some special characteristics that have made it possible for corporate sports to survive in judo in contrast to other sports.

As I have already mentioned, scientific work on the Japanese corporate sports system is rare. There is some research written in Japanese that deals generally with the whole system but by and large only contains the history of corporate sports in Japan and the problem of its break-up since the 1990s. These sources document the development of corporate sports, citing almost exclusively team sports like baseball 
or volleyball, and moreover discuss the different reasons that caused the breakdown in the corporate sports system.

However, these works do not include a description of the system itself. Consequently, I conducted a questionnaire survey on the corporate sports system in Japanese judo. The questionnaire survey is composed of four different parts: one questionnaire addressing corporate judo athletes, one addressing the coaches, one addressing personnel responsible for the judo team on behalf of the company, and one addressing a representative of the National Judo Federation of Japan. My intention, using the questionnaire survey, was to collect as much data as possible on the corporate judo teams in order to make a complete description of how the whole system works. Hence, the questionnaire included questions on entry and recruitment into the company, the management of work and training time, the system of wages and bonuses for the athletes, and their occupational future after their sporting careers. In the questionnaire addressing the National Judo Federation of Japan I was interested mainly in the role of the Federation concerning the corporate judo teams, namely, if they have any influence on the recruitment of athletes or if there exists any other cooperation with the companies. The survey represents the main source for this work, especially for the description of the system of corporate sports. ${ }^{1}$

\section{A brief history of corporate sports in Japan}

The starting point of corporate sports in Japan, as they are represented in their basic form up to the present, dates from around the beginning of the 20th century. After the introduction of modern sports from the West to Japan at the time of the Meiji Restoration in 1868, sporting practice was concentrated in school sports. However, some years before the advent of the new century, corporate sports teams appeared and were invited to compete with school teams. At that time, sports were initiated in companies as a part of social services for the employees and with the intention of contributing to their health. The idea was, moreover, that sports activities should strengthen the sense of community and the sense of solidarity among them. This kind of corporate sports was called shokuba supōtsu 職場スポーツ (workplace sports) (Saeki 2004: 32). Sports at the workplace had nothing to do with good results in sporting competitions, as in most corporate sports teams today. Formerly it was just intended as a benefit for the employees.

Around the turn of the century there were only a few teams, but especially during the Taishō Period 大正時代 (Taishō jidai, 1912-1926), companies began to establish their own teams. Corporate sports teams, mostly baseball teams, appeared one

1 Information from the questionnaire survey will be cited with the term 'questionnaire survey' (q. s.) in the text. Unless otherwise stated, all translations into English from Japanese or German are my own. 
after another. At that time baseball began to gain popularity in Japan, especially among students, and companies concentrated on this American sport, which had been introduced into the country at the beginning of the 1870s. For this reason, the beginning of corporate sports in Japan is always related to baseball (Ohno 2002: 30). It was the National Railway of Japan that established most of the first corporate baseball teams. Different branches all over Japan built their own teams with their employees and as a result of the rapid diffusion of teams all over the country, a National Baseball Championship of the National Railway was organised in 1921 (Sawano 2005: 66-67). The National Railway was the first industry to engage in promoting sports as a benefit for employees. However, as the number of teams increased continuously and competitions between corporate teams were held, the reasons for establishing a sports team changed from those of health and solidarity to those of success and good results. Sporting competition became more important.

Following the National Railway, heavy industry as well as the textile industry began establishing corporate sports teams just before the breakout of World War II. While heavy industry concentrated on baseball teams for men, companies in the textile industry built volleyball teams for women. Nevertheless, all companies had to cease their sporting activities from 1940 until 1945 because of the state of war (Saeki 2004: 33).

After the end of World War II, sports in Japan came back to life and so did the corporate sports. It was still the same industries that promoted sports in their companies, and in 1946, baseball competitions for corporate teams were also introduced again. The overall corporate sports system experienced a revival with the establishment of several new teams (Saeki 2004: 33). The consolidation of this system, which took place so soon after World War II, represents the basis for the corporate sports boom from 1955 until the 1990s. More and more companies, from the automobile, the electronics and the chemicals industries as well, began establishing corporate sports teams. One reason for the sports boom in general was the hosting of the 1964 Olympic Games in Tōkyō. National leagues for football (1965) and for volleyball, basketball and ice hockey (all 1966) were established and thus constituted a new arena for competition for the corporate sports teams (Ohno 2002: 24).

However, this boom ended abruptly at the beginning of the 1990s. This period indicates the beginning of the breakdown in the Japanese corporate sports system (Saeki 2004: 35). The economic recession forced many companies to close down their sport teams or at least to suspend the team temporarily (Ohno 2002: 25). Between 1991 and 2000, 149 corporate sports teams in team sports (mostly baseball, volleyball and basketball) and 64 teams in individual sports (track and field, table tennis, tennis, ski, badminton, gymnastics, sumo and others), namely 213 teams in total, were closed down because of economic problems caused by the recession. The high point concerning the number of teams terminated was reached in 1999, when 
about 60 teams had to stop their sporting activities (Watanabe 2005: 208). These figures make it clear that team sports were worse affected than individual sports.

At present a change in corporate sports in Japan is in progress. Several teams in different sports, which were shut down temporarily, have been revived and converted into regional sports clubs. They are now fostered mainly by regional public facilities. In general, Japanese companies no longer own sports teams, but support them at least financially (Ohno 2002: 25). Tamaki Masayuki 玉木正之 (2006) states that the basic form of Japanese corporate sports with a company as the owner of a corporate sports team is no longer the ideal form of sports promotion. It is thus necessary to think over the organisation and the system of sports in Japan (Tamaki 2006: 118).

\section{Jitsugyo jū $\bar{u} \bar{o}$ - judo in Japanese companies}

The term jitsugyō jūdo 実業柔道 (corporate judo) denotes the promotion of judo by a company. More precisely, employees who enter the company as athletes and members of the corporate judo team are guaranteed a stable livelihood through the company and are allowed to give precedence to their sporting activities over work. This whole system of corporate judo teams is named jitsugyō jū $\bar{u} \bar{o}$.

At the present, corporate judo teams are very important institutions for Japanese judo as regards competitive sports. From the 1992 Olympic Games in Barcelona to the last Olympic Games in Běijīng in 2008, always more than half of the Japanese Olympic judo team was composed of athletes from corporate judo teams. While there were eight out of 14 corporate athletes in Barcelona in 1992 (Kindai Jūdō 1992: 129), there were already nine out of 14 in Atlanta in 1996 and in Sydney in 2000 (Kindai Jūdō 1996: 80; 2000: 62). This tendency did not stop and so there were 11 out of 14 corporate athletes in Athens in 2004 (Kindai Jūdō 2004: 62) and finally one student and 13 corporate athletes competing in the Olympic Games in Běijīng in 2008 (Kindai Jūdō 2008b: 42). These figures indicate the great importance of the system for Japanese judo and show that companies do a good job in promoting sports, especially competitive sports.

However, it is not just the strength of the corporate judo athletes that indicates the importance of corporate judo teams, as well as the great number of teams. Every year individual and team championships for corporate judo take place. In 2008, there were 107 men's teams in all of the three different leagues of the team competition. Although teams with a great number of athletes take part with more than one team in a team event, there still exist about 100 corporate judo teams for men in Japan. On the other hand, there are not that many teams for women and in 2008, the two women's leagues consisted of 18 teams (Kindai Jūdō 2008a: 85-86). 
In the following sub-sections I will make a detailed description of corporate judo teams that promote competitive judo in Japan.

\section{Entry into the company - recruitment methods}

In general, there are two ways to enter a company as an athlete of a corporate judo team. First, an athlete can make an application to the company, or second, an athlete is hired by a company (q. s.). However, there are certain differences in handling these two methods of recruitment, depending on the companies. Moreover, every company has its own criteria and standards for athletes entering the corporate judo team.

The questionnaire survey indicated that 12 out of the 19 male and female corporate judo athletes stated that they entered their company because they wanted to do so, meaning they made an application to the company by themselves. The procedure up until entry into the company followed almost the same pattern in all cases. The athletes chose a company they would like to join, then established contact with the head coach of the corporate judo team. After the head coach's agreement and further acceptance by the company as well, they were employed as an athlete in their desired corporate judo team. One female athlete indicated that she was invited to a practice session, during which she was observed by the coaches. Afterwards she was accepted for the corporate judo team (q. s.). Athletes who have not achieved good results in national championships up to the time they are to join a company often have to show their potential in a practice session. On the other hand, athletes who already compete at the top level have been observed in competition all the time. The personal application by athletes mentioned here is not comparable to a normal job application. They are not valued on their abilities for a job in that company, but on their potential in judo in order to compete on a high level in international competitions. The athlete therefore addresses the coach, who comes to an agreement with the company concerning recruitment. Sometimes high school or university coaches make the contact with the coaches of corporate teams.

The remaining seven athletes questioned in the survey were invited by the coach of a corporate judo team. In those cases the coaches of the corporate judo teams acted as scouts, who went to see competitions of different age groups to find talented athletes for the future and then asked them to enter the company. Scouting is one of the most important tasks of corporate team coaches. Mostly they watch national championships, not regional competitions, because the national level is the standard for selection of an athlete in most of the companies. Moreover, there are certain differences concerning scouting activities for male or female talents. Whereas some coaches of women's teams even watch competitions of elementary school students, coaches of men's teams start scouting talented athletes from university level up- 
wards (q. s.). Thus, competitors in national championships are mostly observed and maybe even contacted by scouts from corporate judo teams.

As already mentioned, each company also has its own criteria in deciding which kind of athletes to recruit as members of its corporate judo team. In general, companies employ students who have just graduated from university, but in some cases, some companies also recruit high school graduates. In the questionnaire addressing personnel in the company responsible for the judo team, the two persons I interviewed both emphasised that there are criteria on which they base their choice of athletes. However, these criteria are not explicitly determined or written down. The company, co-operating with the head coach, pays attention to results in competitions and sporting potential for the future, but also to the character and personality of an athlete. One of them added that it is important for his company to employ athletes who are able to co-operate with other people. On the other hand, it is important that the athletes employed have prospects of competing some day in the Olympic Games or World Championships (q. s.). Another criterion is the kind of high school or university an athlete graduated from. Some companies recruit athletes only from certain high schools or universities. One coach of a women's team stated that her company accepts graduates from just one special university, which means that she does not have to do any scouting (q. s.). There are several companies in Japan which traditionally recruit athletes only from certain schools or universities. For example, Shin Nihon Seitetsu 新日本製鉄 (in its abbreviated form Shin Nittetsu 新日鉄 and Japan's biggest steel production company) prefers graduates from Meiji University 明 治大学, Tōkai University 東海大学, Tenri University 天理大学, Tsukuba University 筑波大学, Takushoku University 拓殖大学 and the Nihon Taiiku University 日 本体育大学 (Tanakadate 2000a: 113). These universities are the traditionally strong 'judo universities', meaning that these teams have been the elite of Japanese judo for many years. It is no exaggeration to say that studying at one of these universities connected with good sporting results guarantees employment in a corporate judo team.

However, as there are a great number of judo players in Japanese high schools and universities, not every player will be recruited by one of the best corporate judo teams because every company has a limitation on how many athletes it is able to employ. This limitation does not say how many athletes a company is able to employ every year but it determines the round figure of the team members. The coach, in co-operation with the president of the judo team on behalf of the company, fixes the number of athletes per team (q. s.). I assume that the limit on the number of athletes depends on the financial background of the company as well as on sporting elements, because the team competition for corporate judo teams, which is held every year, plays an important role for the companies. Thus the company and the coach of the corporate team will recruit as many athletes as are necessary to win this championship. Consequently, as there is a difference in the number of competitors 
for the team championship between male and female teams, with men's teams consisting of five competitors in all the three leagues, whereas women's teams in the first league consist of five and in the second league of three competitors. Men's corporate judo teams are thus generally greater in their number of athletes (Kindai Jüdo 2008a: 85-86). To summarise, the company co-operating with the coach limits the total number of athletes in the team and inside that framework they try to coordinate the admission of new team members every year.

\section{Work and sports}

Corporate judo athletes in Japan can be divided into five types. The first is called jūdo yūsen gata 柔道優先型, which means that this kind of corporate athlete does not have to work at all, but is required to concentrate on practice and competition. The second type is called jūdo yūsen sukoshi shigoto gata 柔道優先少し仕事型 and for this category judo takes precedence over work. However, the athlete has to do some work, for example, several days a week and just in the morning. The third type works for preference, but also practises judo two or three times a week and is called shigoto yūsen sokosoko jūdō gata 仕事優先そこそこ柔道型. Type number four is the reverse of type number two, which means that work comes before judo. This category of athlete practises sometimes and also takes part in competitions because they enjoy it. This type is called shigoto yūsen sukoshi jūdō gata 仕事優先 少 し柔道型. The fifth and last type of athletes in corporate judo is called jūdo mo shigoto mo isshōkenmei gata 柔道も仕事も一生懸命型, meaning that such athletes work full-time and moreover practise judo every day. This category makes the greatest effort in the system of corporate judo (Manabe 2005: 98). This description of the different types of corporate athletes in Japanese judo shows that there are several possibilities for continuing with judo practice after graduation from high school or university.

According to the questionnaire survey, 17 out of 19 athletes indicated that they also work besides practising judo. Some of them work three days a week and only in the morning, whereas the others work five days a week. The remaining two athletes stated that they were not obliged to work; their work was judo (q. s.). When it comes to combining work and practice, these two different kinds of athletes comply with type one, mentioned above, who does not work at all, and type two, who works just several days a week. For both types, however, judo is their main duty in the company.

Depending on how work and training time are managed, there are different kinds of employment and denomination among corporate judo players. According to the classification by Watanabe Tamotsu 渡辺保 (2005), all 19 athletes questioned in the survey would be called senshu shain 選手社員 (sports before work-type). Although 
this type of athlete is hired as an ordinary employee of the company, they are allowed to practise all day or at least the whole afternoon. From the point of view of work, the senshu shain works not at all or only some days a week in the morning. The reverse case of this kind of athlete is the shain senshu 社員選手 (work before sports-type), whose training time is not included in their work time, meaning that they practise after their full-time work duties. These two forms of employment are sub-divisions of the seishain 正社員 (ordinary employee) among corporate sports athletes. On the other hand, the Japanese corporate sports system does contain keiyaku senshu 契約選手 (contract athletes). These contract athletes are not regularly employed in the company, but are under contract to it. In the category of keiyaku senshu, there is a distinction between a shokutaku senshu 嘱託選手 (limited contract athlete), who has a fixed-term employment contract with the company, and a puro keiyaku senshu プロ契約選手 (professional contract athlete), who has a contract just as a professional athlete without work (Watanabe 2005: 213, 216-217).

In Japanese corporate judo, the two types of contract athletes are nearly nonexistent. Just one company, Mikihouse ミキハウス (producing children's clothes), recruits only professional contract players. In 2007, Mikihouse promoted 14 contract athletes from different sports, among them two judo players, one male and one female (Mikihouse 2008). The most common form of employment in corporate judo, however, is represented by the senshu shain, as already seen.

The kind of work corporate athletes have to accomplish depends on the company, but the most common is office work. Thirteen out of the 19 respondents to the survey stated that they were engaged in paper work, entering data in a computer or answering the telephone in the office. Three female corporate judo players replied that they worked as salespersons in a shop that was a branch of their company. Another kind of work was characterised as advertising activity by one female athlete. Her questionnaire showed some ambiguity over the kind of tasks she undertook, but it can be assumed that she was the subject of advertising for the company. To my knowledge, this female athlete is very successful compared to her colleagues, who stated they did office work. For this reason I conclude that especially successful athletes are employed for advertising purposes. The remaining two out of the 19 athletes questioned were those who do not have to work at all (q. s.). In short, it can be said that in general the kind of work corporate judo players are obliged to do is dependent on the company, and in particular on the kind of company, but that there is a tendency towards office work. The most important point, however, is that in companies where sports come before work, corporate athletes are not burdened with work, so that they are able to concentrate on their sporting duties.

As sports take precedence over work in most of the cases in corporate judo, the question arises of whether results in judo have an effect on the continuance of their employment in the company as corporate athletes. According to the survey, there are companies where athletes are allowed to stay in the company regardless of their 
success in sports, and those where sporting results have an impact on their employment, meaning that they can be laid off when results are insufficient. The first instance relates to those companies whose athletes work at least some days a week, whereas the second concerns companies whose athletes' work is judo (q. s.). In the second case, where corporate judo athletes do not have to work at all, it is clear that sporting results are of greater importance than in other companies, which also value the working skills of their corporate athletes. However, in general, the employment of corporate judo athletes is assured regardless of sporting results.

Concerning the combination of work and practice in companies with corporate judo teams, it can be said that there are certain differences depending on the company. Every company has its own style of handling the corporate judo team, namely, how work and practice time are managed, which kind of employment the athletes have and if sporting results have an impact on their employment in the company.

\section{Wage and bonus system}

In general, corporate athletes are subject to the same wage and bonus conditions as ordinary employees. However, as in most cases athletes are not able to work overtime because of their sporting duties, a special allowance is paid just for them. Moreover, a premium bonus system for corporate athletes exists in most companies (Watanabe 2005: 215). The system described here is commonly applicable to all sports in the Japanese corporate sports system and therefore represents the basic model for wages and bonuses.

There will, of course, be variations depending on the company, and so it is in judo. The results of the survey made clear that every company pursues its own style in remunerating its athletes. Three female athletes indicated that their wage was the same as that of ordinary employees. In contrast, most of the remaining women surveyed (ten out of 15) stated that their wage was dependent on sporting results. Among the male respondents, the majority (three out of four athletes) also emphasised their wage dependence on sporting success. The better the results in competition, the higher the wages. One respondent stated further that the basic wage of corporate athletes was itself already higher than that of ordinary employees (q. s.). These answers are an indication of the special position of corporate athletes in companies in comparison to ordinary employees; this does not, however, apply to every company in the Japanese corporate sports system. In general, wages are dependent on sporting activities, namely good results in competition.

Where good results are concerned, a premium bonus system also operates in most of the companies with corporate sports teams. In the case of judo, medals at Olympic Games or World Championships are rewarded with special bonus payments. Eighteen out of 19 respondents confirmed the existence of bonus payments in 
the case of special success in the so-called big events. Just one male athlete denied that he was paid a bonus for high achievement in judo, the reason being that he worked at a university, that is, a public institution, as a member of the office staff. Although such institutions also participate in corporate judo in Japan, they reveal some differences to ordinary companies, especially concerning the wage system. There is no bonus system in public institutions with corporate judo teams (q. s.).

In order to gain insight into the wage and bonus system of corporate sports companies, I want to cite the example of Asahi Kasei 旭化成 (involved in materials science and production of chemicals), which has been a traditional, very successful company within the system of men's corporate judo. Although athletes of this company have been successful over the years and still are today, which could be a sign of a total promotion of sports without work, Asahi Kasei has always attached great importance to the working duties of its athletes. The payment system in this company is divided into two parts. On the one hand, there is the basic wage for athletes and on the other, the bonus system for special success in competition. The basic wage is determined by an athlete's potential in sports as a whole, not by their potential at work. If an athlete has constantly good results in competitions over a year, he or she is able to rise in the wage system the following year. Where bonuses are concerned, it is not sporting results as a whole, as in the basic wage system, but particular single results like wins or medals in big events or even national championships that are rewarded with extra payments (Ōno 2000: 163-164). This initial brief description of the wage system of a company with a corporate judo team backs up the answers of the respondents in the survey, who also emphasised the dependence of wages on sporting results and the existence of a premium bonus system.

The basic wage of athletes is divided into different levels, starting from $\mathrm{E}$ and following through to D, C, B and finally A. At the A-level, there is a further division into A, AA and AAA. Category AAA includes athletes who have won a gold medal in the Olympic Games or World Championships. Athletes who are number one in their weight category in Japan are positioned at level AA. Wage level A caters for athletes who are on the way to becoming number one in Japan or at least have the potential to do so. Category B includes average athletes, whereas athletes who did not obtain good results before their entry into the company will be categorised at levels C, D or E. For athletes as well as for ordinary employees, wage level classification is carried out annually. However, in the case of athletes classification is easier than for ordinary employees, because it is possible to make a clear distinction between winning or losing in respect of sufficient or insufficient sporting results. For purposes of classification, the coach of the corporate judo team talks to each athlete about their sporting results and achievement of their own aims as determined the previous year. In contrast, ordinary employees have to write a report on their aims and if they can realistically be attained. This report is then assessed by a senior employee two grades above the employee being evaluated. On the basis of the senior 
employee's evaluation, the subordinate employee is classified into the appropriate wage level.

Another big difference between athletes and ordinary employees is that for athletes it is possible to vault over some wage levels in the space of a year if the sporting results rise spectacularly in that time, for example, from an average athlete to the number one in Japan within one year (Ōno 2000: 165-166). On the other hand, however, athletes are always put at risk of getting badly injured and, as a result, of not being able to compete. In such cases, the company assures no decline in wage level for a determined period of time. Depending on the degree of injury, athletes do not drop back in the wage scale for about one or one and a half years. After that deadline, athletes can fall back in their wage levels if they do not achieve sufficient sporting results. A further particularity in the wage system of corporate athletes at Asahi Kasei is the steady reclassification from the athletes' wage system to the ordinary employees' system after athletes finish their sporting career. First of all, athletes drop level by level in the athletes' wage system and then start anew from the first level in the ordinary employees' wage system and work their way up (Ōno 2000: 170).

\section{Job prospects after a sporting career}

Athletes, as strong as they may be, are not able to perform in competition for the whole of their lives. Professional golf players are able to compete until the age of 50 or 60 , but in most sports top performance is possible until the age of 30 or maybe 35. Only a few outstanding athletes in certain sports manage to keep up successfully until the age of 40 or maybe even 45 . The problem then arises of what to do after the end of a career in sport. Among Japanese corporate athletes some aim at becoming a coach or a sports commentator for a TV station. Another possibility might be employment in the national federation of the sport they formerly practised. The alternatives to staying in sports would be employment in the company, establishing their own business or continuing their parents' business, if there is one (Ōno 2000: 6667). For top athletes in different sports, especially in minor sports, in which not much money can be earned by sporting achievements, the question of job prospects is raised. They have to decide whether to stay in sports as a coach or in any other position, or take up a completely different profession.

An important point on this subject is the question of whether companies with corporate judo teams offer their athletes the possibility of staying in the company even though they have retired from their active sporting career, or if the athletes are forced to leave the company as soon as they finish with judo. The question about occupational prospects after a career in sport brought a clear result: 16 out of 19 respondents stated that they would have a secure job in the company where they 
were employed as an athlete. The remaining three persons did not give any information on whether or not they could stay in the company. They only mentioned that they would like to stay or that they wanted to become a high school teacher or a university professor in the future. However, even though corporate athletes are allowed to stay in the company after their sporting career, only four out of 19 had the desire actually to work there in the future. Whereas eight persons did not want to stay, seven of them were not sure yet about their future (q. s.). In summary, it can be said that the Japanese corporate sports system is obviously organised in such a way that employment after a sporting career is secured. Nevertheless, corporate athletes are apparently not forced to stay, but can freely choose which kind of profession they want to carry out in the future.

In some companies, for example, Asahi Kasei, athletes are expected to stay in the company in whatever position (Ōno 2000: 14-15). The same approach is taken by Shin Nittetsu, where athletes are recruited as ordinary employees, work in the company besides practising judo throughout their active career and stay in the company to continue working there after they retire from sports (Tanakadate 2000a: 111). By way of an alternative, Ryōtokuji Gakuen 了徳寺学園 (vocational school for sports medicine as a profession) offers their athletes attendance in the school's vocational programme. It has to be said that Ryōtokuji Gakuen employs judo athletes as staff in their school in the framework of corporate sports. They do not have to work at all, but are expected to concentrate on judo and are guaranteed a stable livelihood. However, after the end of their sporting career the athletes do not have a working place in the school as they did not work throughout their career. Nevertheless, the school offers them the chance to attend vocational training to become a physical therapist, for example. Another option would be to become a coach or teacher at a school. For that reason, the athletes of Ryōtokuji Gakuen go on studying at their university after they enter the company. Most of them continue with a masters programme to achieve the qualification for becoming a coach or teacher. In addition to the possibilities of a master's degree or vocational training, Ryōtokuji Gakuen offers a wide range of further education, which can be attended throughout their sporting career, such as English and computer courses or lectures by successful persons on different subjects (Manabe 2003b: 107).

To sum up, the Japanese companies with corporate sports teams provide employment or at least vocational training so that the occupational future for their athletes is secured. In companies, or in the case of Ryōtokuji Gakuen, where the athletes do not work at all throughout their sporting career, the athletes themselves make arrangements for the time after that career ends, and they are promoted by the company in whatever they aim for. 


\section{The break-up of the Japanese corporate sports system}

With the economic recession at the beginning of the 1990s, Japanese companies closed down their corporate sports teams as a measure of downsizing. Such actions mark the starting point of the break-up of the Japanese corporate sports system (Watanabe 2005: 203). Especially in team sports, expenditure for athletes, for sporting facilities, for administration, and for travel and accommodation in the case of training camps, away games or competitions is extremely high. Consequently, ownership of a corporate sports team is connected with high financial risk (Watanabe 2005: 210). This high risk resulted negatively in the closure of corporate teams in the 1990 s, and it was the beginning of the crisis in the corporate sports system in general.

If one is talking about the breakdown in the corporate sports system in Japan, the economic recession of the 1990s is always mentioned. However, the recession was not the only reason for the corporate sports crisis with its certain collapse of corporate teams (Saeki 2004: 4). Besides the bad economic conditions at that time, other factors forced Japanese companies to close down their corporate sports teams.

From the end of the 1980s, interest in corporate sports through the media declined with the first appearance of the kanmuri taikai 冠大会 (title-sponsored events or 'crown' events) (Saeki 2004: 42). Kanmuri taikai are sporting events, championships or competitions that bear the name of the sponsor or the name of a sponsor's product in the title of the event (Chūjō 2001: 131). Such a special kind of eventsponsoring in sports had the effect of displacing corporate sports, with the consequence that companies changed their strategy for the promotion of sports from ownership of a corporate team to sponsorship of sporting events. Saeki Toshio 佐伯年詩 雄 (2004) explains that from the viewpoint of advertising impact, it is more effective for companies to sponsor big sporting events than to own a corporate sports team, since the advertising effect through a corporate sports team is always dependent on their sporting results. By contrast, the sponsoring of a sporting event has more controllable factors and therefore offers more security for the finances of the company (Saeki 2004: 47). The sponsoring companies invite international superstars in order to attract people to come and watch the event. Moreover, successful popular athletes from abroad arouse the interest of TV and other media, which brings advertising advantages for the sponsoring companies (Saeki 2004: 45). The value of the advertising impact through their presence in the media exceeds considerably the costs of inviting international athletes.

Through these kanmuri taikai, the internationalisation and professionalisation of sports also advanced. The participation of star athletes from abroad in sporting events in Japan focused the media's attention more and more on international sports and subsequently, interest in Japanese corporate sports decreased on the part of the media and on the part of the Japanese people (Saeki 2004: 42-43). On the other 
hand, professionalism was nurtured through entry fees and prize money, which sponsoring companies paid to star athletes in order to attract them to participate in competitions. This strengthened the awareness of athletes to becoming professionals (Saeki 2004: 48). Professionalism not only caused a decrease in interest in corporate sports but also displaced national leagues for corporate sports athletes by professional leagues, especially in team sports like football or baseball.

In short, the total effect of factors like economic recession, title-sponsored events as a new form of sponsorship in connection with sports in the media, internationalisation and professionalism was such as to lead to the break-up of the corporate sports system in Japan. The interaction of these factors produced a mechanism whereby corporate sports became less important for the media and for the Japanese people in general, and as a result several teams were forced to close down.

\section{Prerequisites for the preservation of corporate judo teams}

Although many corporate sports teams have closed down since the 1990s, corporate judo teams seem not to be affected by the crisis in the corporate sports system in Japan. It is clear that there have been no break-ups of important corporate judo teams, and the number of teams has been constantly on the same level for years. The reasons for the preservation of corporate judo teams in Japan are as diverse as were the reasons for the breakdown of many corporate teams mentioned in the previous section.

First, it seems that the economic recession was a decisive element in the process of the collapse of corporate sports in Japan. When it comes to sports clubs, the financial means for sporting facilities, exercise machines or fitness devices as well as for coaches and other staff are indispensable. However, financial sources are limited and depend on the organisation or company that administers the club. It is therefore important to use the available money effectively (Kikuike 2004: 36). As sporting activities and, moreover, the administration of a sports club or team require money, sports are dependent on the state of the economy as well as on the economic condition of the company that promotes the sporting activities. This kind of economic dependence caused the breakdown of many teams in the corporate sports system in Japan.

In judo, however, it can be seen that such dependence did not cause any damage because of the difference in the overall cost for individual and team sports. Judo as an individual sport is considerably cheaper in contrast to team sports like baseball or volleyball. Companies that manage a corporate judo team often emphasise the advantage of the lower costs of judo. For example, Keiyō Gasu 京葉ガス (a supply company for gas and electric energy), which has a traditionally strong judo team that won the title in the second league of the Corporate Team Championship in 2008, 
established its judo team in 1972. However, it seems that no other reason was named for the decision to promote judo apart from the financial one. One of the company's officials said that it could have been any other sport; however, the lower costs of judo as an individual sport counted decisively for judo and against baseball or any other team sport (Manabe 2001a: 103). Companies with corporate judo teams have always tried to preserve the judo team even in times of economic recession. That is to say, even though the closing of a judo team would have brought financial relief to the company, most of the companies have tried to continue the promotion of judo. Asahi Kasei's judo team has outlasted several financial crises in its 50 years of existence, and thanks to the company still exists today. The board of management strove, sometimes with minimal finances, to save their judo team (Ōno 2000: 2-3). The lower cost of judo as an individual sport and the commitment to promoting judo have prevented corporate judo from being broken up.

The reason for companies' commitment to promote judo, even in times when they have financial problems, lies in the different reasons why corporate judo teams were set up originally. In a series entitled jitsugyō jū $\bar{u} \bar{o}$, Kindai Jūdō 近代柔道, a Japanese monthly judo magazine published by the Baseball Magazine publishing company, presented and described 36 corporate judo teams nearly every month in the period from August 2000 to October 2006. As 11 out of the 36 companies did not mention the reason for the establishment of a judo team, I analysed the remaining 25 teams. The conclusion of this analysis is that not one team stated that the impact of advertising, meaning the financial component, or advancement of the company's image through ownership of a corporate judo team was the decisive factor in the promotion of judo. The most frequent answer was 'the company director's interest in judo' (six times; Manabe 2001a: 102-103; 2004b: 33-34; Tanakadate 2000a: 110; 2000c: 103; 2001a: 105; 2001b: 118). The second answer was that 'there were several judo players employed in the company by chance' (four times; Manabe 2003c: 101; 2003d: 101; 2004a: 93-94; Tanakadate 2000b: 110). Other reasons were, for example, the pressure of shakai kōken 社会貢献 (social commitment or service), namely, 'to provide athletes, who were forced to quit judo because of their job, the chance to continue their sporting activities besides working in the company' (two times; Manabe 2002b: 114-115; 2002c: 98), 'the development of top athletes and the promotion of judo as competitive sports' (Manabe 2003b: 106), 'advancing their employees' toughness through judo' (Manabe 2001b: 98-99), 'the sense of duty to promote judo because of their athletes' constant success for many years and because it is the only original Japanese sports that is in the Olympics' (Manabe 2002a: 99), and 'the point of view of many companies that judo players are good workers and persons with a good personality that comes from the hard training and educational aspect of judo' (Manabe 2003a: 98; 2006a: 102). These answers make it clear that establishing and furthermore owning a corporate judo team is not based on the intention to gain financial advantage. Judo, namely the promotion of 
judo itself, is obviously the main goal of the companies. That is why most of the companies attach importance to the continuance of their corporate judo team.

The reasons for establishing corporate judo teams have also played an important role in the preservation of corporate judo in connection with sports marketing. It has been mentioned already that media interest in corporate sports decreased because of internationalisation and professionalisation in Japanese sports and that this caused the closing of several corporate teams. Moreover, title-sponsored events seemed to have a negative impact on the ownership of corporate sports teams, as many companies changed from owning a team to sponsoring events.

In judo, however, according to the reasons discussed above for the establishment of corporate judo teams, the advertising impact through the presence of these teams in different media seems not to be as important as the promotion of judo itself. The continuance of the corporate judo team is therefore not dependent on the financial factors of advertising and media. Judo is still a popular subject for any kind of media in Japan. For many years, television broadcasting of judo competitions has been popular and remains so today. Corporate athletes appear on TV when they compete, and in addition profiles or interviews are often shown. Moreover, some of the Japanese judo players even star in commercials on TV. In the result of a survey of 2007 about athletes who are often deployed in commercials, one female judo player named Tani Ryōko 谷亮子, a five-time Olympic medallist and seven-time World Champion, was also on the list. She acted in commercials for two different companies (Kurasawa et al. 2008: 67). In addition, TV broadcasts on judo are also a favoured topic in newspapers or sports magazines. The overall presence of judo in the Japanese media is not poor, but the decision by companies whether or not to continue ownership of a corporate judo team is not dependent on advertising and media impact, meaning it is not absolutely essential.

The second point in the context of sports marketing is the new form of sports sponsoring by Japanese companies as the main promoter of title-sponsored events. In judo, as is apparent from the great number of corporate judo teams still existing today, event-sponsoring has not displaced ownership of a team. Rather, companies have added the sponsoring of judo events to their promotion of corporate judo teams. In short, companies are engaging in an overall promotion of judo through ownership of corporate teams and the sponsorship of events. The homepage of the Japanese Judo Federation (Zennihon Jūdō Renmei 2008), in the section on information about competitions, carries announcements for national and international competitions in which all sponsors, main sponsors and others, are listed. Among these sponsoring companies, those who own a corporate judo team are listed separately. Some events are only title-sponsored, for example the Kindai Jūdō Cup 近代柔道杯 for students of junior high schools, which is organised every year in March by Kindai Jüdō magazine. Most of the judo tournaments do not have the name of a company in their title, thus they are not categorised as title-sponsored events, but actu- 
ally these events too have the same pattern, with one main sponsor and many other sponsoring companies. Main sponsors in title-sponsored events, however, are responsible for the entire promotion before the event takes place and moreover have to organise the whole event except the direct holding of the competition, which is entrusted to the relevant federation (Saeki 2004: 48). I believe that the dominance of common event-sponsoring, where the sponsoring company fosters the event financially but stays somewhat in the background, in contrast to the main sponsors of title-sponsored events, is further proof of companies' awareness that the promotion of the sport of judo itself, and not the advertising effect for the company through judo, is the most important thing.

The last missing factor in the total of determining elements for the breakdown of corporate sports teams, as well as for the preservation of corporate judo, is professionalism in sports. Through the appearance of professional leagues mostly in team sports, the corporate sports system suffered a setback, as is highlighted through the collapse of several corporate sports teams.

In contrast, judo is still referred to as an amateur sport and therefore the corporate sports system in judo is still in existence. The difference between an amateur athlete and a professional athlete lies in the definition of occupation. Amateur athletes are persons who have an ordinary occupation besides their sporting activities, which are carried out as a leisure activity (Tamaki 2006: 92). The most important thing is that the athlete does not earn money through their sporting activities, only through their job. On the other hand, professional athletes make their living through sports, that is to say, their occupation is the practice of sports. Furthermore, among professional athletes, there are three different possibilities for earning money. The first are athletes who are paid by their team or any other sports organisation they belong to, for example, professional baseball, boxing, football or even sumo. The money paid out as salary comes from entrance fees to games, tournaments or other competitions, from TV funds or from sponsors. The second case would be sports like horse races, cycle races, car races or boat races, where athletes are paid by the money from spectators' bets. The third possibility concerns mostly individual sports like tennis or golf, where athletes make their living by prize money (Takahashi 2004: 156). In judo, none of these three possibilities of remuneration has existed up to the present. It is still thus without doubt an amateur sport. In 1993, Takita Seiichirō 滝田誠一郎 drew a graph showing the positioning of different kinds of martial arts, wherein he placed judo clearly between competitive sports and amateur sports (mass sports) and not on the side of professional sports (Yamazaki 2004: 95). However, there has been a slight tendency towards professional sports status even in judo. Some years ago, the International Judo Federation started to hold special tournaments with prize money, in which just a few selected athletes, namely, the most successful ones, were allowed to participate. In 2001 and 2002 such tournaments were held for men and women (Onoda 2001: 10-13; Ōsako 2002: 26-27). Neverthe- 
less, as these tournaments have not been held regularly - just once a year or once in two years-, it cannot be said that athletes could make a living out of the prize money. Moreover, not everyone but just some selected athletes were allowed to participate. From the year 2009, a new tournament plan with one Masters Tournament, several Grand Slam and several Grand Prix Tournaments has been introduced, in which prize money amounting to US $\$ 200,000$ or $\$ 150,000$ will be paid out to the athletes up to third place (Shibata 2008). It is a first attempt to make judo professional but Willi Könning (1990) states that 'in general all athletes appreciate professional sports, but the rate of acceptance in typical amateur sports, like martial arts or rugby, is noticeably lower' (Könning 1990: 80).

In several sports, especially team sports like baseball or football in Japan, professional leagues have been introduced and so corporate sports have become less important. In corporate judo there is a tendency towards professional athletes, who do not have to work at all but need to concentrate on judo. However, the tendency towards professionalism does not destroy the corporate system with an inevitable closing of teams; it just causes the system to change, for example, in the management of work and practice time. Today there exist teams whose athletes work, and others whose athletes do not have to work at all. Nevertheless, all these athletes are seen as amateurs or as semi-professionals. The term 'semi-professionalism' indicates a middle course between amateur and professional sports and is often mentioned when talking about the Japanese corporate sports system of today (cf. Sawano 2005: 133141). A semi-professional is an athlete who is not an amateur anymore but is not yet a professional. That is to say, this kind of athlete lives like a professional as far as his life-style and his concentration on practice are concerned, but he is not able to make a living just from his sporting practice; he does not earn money through sporting results. Athletes who do not have to work at all are nevertheless dependent on the company that promotes their sporting activities and guarantees them a stable livelihood.

\section{Conclusion}

The corporate sports system in judo in Japan has obviously overcome the crisis that led to the collapse of several corporate sports teams. The factors that forced companies to close down their teams or suspend them temporarily did not have a negative impact on corporate judo teams. The reasons for the preservation of corporate judo teams mentioned in the analysis contained in the section on 'Prerequisites for the preservation of corporate judo teams' can be confirmed through the statements by responsible persons of corporate judo teams, who were asked about the Japanese corporate system in the questionnaire survey. 
The Japanese judo national team coach, who was questioned as a representative of the Japanese Judo Federation, named the high significance of judo in Japan, achieved through traditionally big successes in Olympic Games over many years, as one of the main reasons for the preservation of corporate judo. He stated further that the low costs for judo as an individual sports in contrast to team sports had a great impact on companies in encouraging them to continue promoting judo (q. s.). Watanabe (2005) as well remarked that judo, marathon and other track and field events constitute a lower financial risk for companies and hence, the corporate sports system still exists in these sports in Japan. Tournaments and competitions in judo and marathon are often broadcast on Japanese TV, and so owning a judo or marathon team brings several advantages to companies. In Watanabe's opinion the future of corporate sports in judo and marathon (track and field as a whole) seems to be secured (Watanabe 2005: 210). Low costs, success in sports and a positive advertising effect have been analysed above ('Prerequisites for the preservation of corporate judo teams') as elements leading to the preservation of corporate sports in judo.

Those responsible on the part of the company for corporate judo teams have explained that first of all, the promotion of judo as a measure of social service (shakai $k \bar{k}$ en) was the most important reason for establishing such teams. As a professional league or competitions just for professionals in judo do not exist, as they do in baseball or football, the corporate sports system is a very important institution for judo as a competitive sport. It offers the only possibility of continuing judo as a top athlete after graduation from university and entry into working life. Companies with corporate judo teams want to show children that it is also possible to become a successful and popular top athlete in judo and not just in baseball or football (q. s.). In stating this, the advantage of sports promotion as social service, the absence of professionalism in judo and the promotion of judo for adults after graduation from university are mentioned as aspects in favour of the corporate sports system.

Although the corporate sports system still exists in judo in Japan, there have been several changes in the structure and management of corporate judo teams, and change has occurred in numerous areas up to the present. On the other hand, there are also teams that try to resist these changes and to go on promoting judo in the same way as hitherto.

The original Japanese model of corporate sports supposes that only company employees are able to become members of the corporate sports team. Top athletes from high school or university look for a company after graduation and start to work there while practising judo to a high level. The company promotes the sporting activities of their employees, offering perfect conditions for practice and competition. This is the basic model of Japanese corporate sports (Tamaki 2006: 104). Especially in corporate judo, most companies have always emphasised the importance of working in addition to judo because they want their athletes to continue working in the company after the end of their sporting career. Shin Nittetsu, for example, has tried 
to manage their judo team in this basic style with a combination of work and sports from the establishment of the judo team in 1950 right up to today. However, it is becoming more and more difficult to recruit top athletes because most of them decide to enter a company in which they are allowed to concentrate on practice and do not have to work. The slow-going transformation to professionalism in corporate judo complicates the recruitment of athletes in a company like Shin Nittetsu and thus the number of athletes decreases. Nevertheless, Shin Nittetsu still tries to stick to the principles of the basic corporate sports model, even if it is hard for it (Tanakadate 2000a: 111).

Two teams in corporate judo have already realised the modern form of corporate sports. Ryōtokuji Gakuen and Jieitai Taiiku Gakkō 自衛隊体育学校 (the Military Physical Education School), both types of vocational schools and not ordinary companies, allow their athletes to concentrate on judo without having to work. The athletes at Ryōtokuji Gakuen do indeed have the status of members of staff at the school, but they do not have to work. The head coach of the team explained that nearly all top athletes in Japanese judo live as professional athletes with everyday practice, training camps and competitions and therefore do not have the time to work. Moreover, he criticises the way in which many companies deny that their athletes are actually not working because of the fact that judo is still an amateur sport. They in turn often denounce the style of corporate judo at Ryōtokuji Gakuen because their athletes do not work (Manabe 2003b: 106-107). This example makes it clear that it is not possible for basic corporate sports with their combination of work and sports to be maintained generally. However, this generalized statement from the head coach of Ryōtokuji Gakuen must be regarded with care, as there are several corporate judo teams whose athletes work as well as practising, for example Asahi Kasei. Naturally, sporting activities are given top priority; nevertheless, the athletes do actually work.

In conclusion, it has to be said that numerous companies with corporate judo teams still emphasise the basic model of Japanese corporate sports, but new teams with a modern approach towards professionalism in judo are eventually appearing. However, it is not important to decide which system is the better one but to ensure the existence of corporate sports in judo in the future. Therefore, the main goal for the companies should be the promotion of judo in Japan, in competitive sports as well as mass sports. So far corporate judo teams have overcome the financial crisis without damage and the mission for the future will be the contribution of companies to the high success of judo athletes. 


\section{REFERENCES}

Chūjō, Kazuo 中条一雄. “Shōgyō shugi to supōtsu” 商業主義とスポーツ [Commercialisation and sports]. In Supōtsu no shakaigaku スポーツの社会学 [The sociology of sports], edited by Masaru Ikeda 池田勝 and Shinji Morinō 守能信次. Tōkyō: Kyōrin shoin, 2001, pp. 119-137

Kikuike, Hideo 菊池秀夫. “Supōtsu keiei to senryaku” スポーツ経営と戦略 [Sports management and strategy]. In Supōtsu no keieigaku スポーツの経営学 [The science of management of sports], edited by Masaru Ikeda 池田勝 and Shinji Morinō 守能信次. Tōkyō: Kyōrin shoin, 2004, pp. 35-62

Kindai Jūdō 近代柔道. “Dai 25 kai orinpikku baruserona taikai jūdō kyōgi” 第 25 回オリンピッ クバルセロナ大会柔道競技 [Judo tournament of the 25th Olympic Games in Barcelona]. In Kindai Jūdō 近代柔道 14/9 (158), 1992, pp. 129-135

Kindai Jūdō 近代柔道. “Dai 26 kai orinpikku atoranta taikai jūdō kyōgi” 第 26 回オリンピック アトランタ大会柔道競技 [Judo Tournament of the 26th Olympic Games in Atlanta]. In Kindai Jū dō 近代柔道 18/9 (207), 1996, pp. 80-85

Kindai Jūdō 近代柔道. “Dai 27 kai orinpikku shidonii taikai jūdō kyōgi” 第 27 回オリンピック シドニー大会柔道競技 [Judo tournament of the 27th Olympic Games in Sydney]. In Kindai $J \bar{u} d \bar{o}$ 近代柔道 22/11 (257), 2000, pp. 62-67

Kindai Jūdō 近代柔道. “Dai 28 kai orinpikku atene taikai jūdō kyōgi” 第 28 回オリンピックア テネ大会柔道競技 [Judo tournament of the 28th Olympic Games in Athens]. In Kindai Jüdō 近代柔道 26/10 (304), 2004, pp. 62-67

Kindai Jūdō 近代柔道. “Dai 58 kai zennihon jitsugyō jūdō dantai taikō taikai” 第 58 回全日本実 業柔道団体対抗大会 [58th Japanese national team championships for corporate judo]. In Kindai Jūdō 近代柔道 30/7 (349), 2008a, pp. 85-86

Kindai Jūdō 近代柔道. “Dai 29 kai orinpikku pekin taikai jūdō kyōgi” 第 29 回オリンピック北 京大会柔道競技 [Judo tournament of the 29th Olympic Games in Běijīng]. In Kindai Jū dō 近 代柔道 30/10 (352), 2008b, pp. 42-47

Könning, Willi. Spitzensport in Japan. Die Entwicklung des japanischen Leistungssports von 1948 bis 1988 - unter besonderer Berücksichtigung der japanischen Geisteshaltung und Denkweise. Bonn: Dieter Born, 1990

Kurasawa, Misa 倉沢美佐 et al. “Supōtsu bijinesu kanzen kaimei” スポーツビジネス完全解明 [The whole truth about sports business]. In Tōyō keizai 東洋経済 1/26, 2008, pp. 34-69

Manabe, Masahiko 真鍋雅彦. “Keiyō Gasu” 京葉ガス. In Kindai Jūdō 近代柔道 23/7 (265), 2001a, pp. 102-105

Manabe, Masahiko 真鍋雅彦. “Daikyō Fūzu” 大京フーズ. In Kindai Jūdō 近代柔道 23/12 (270), 2001b, pp. 98-101

Manabe, Masahiko 真鍋雅彦. “Tōyō Suisan” 東洋水産. In Kindai Jūdö 近代柔道 24/3 (273), 2002a, pp. 98-101

Manabe, Masahiko 真鍋雅彦. “Takamedikaru” タカメディカル. In Kindai Jūdō 近代柔道 24/11 (281), 2002b, pp. 114-117

Manabe, Masahiko 真鍋雅彦. “Meisō” 明送. In Kindai Jūdō 近代柔道 24/12 (282), 2002c, pp. 98-101

Manabe, Masahiko 真鍋雅彦. “Sentoraru Keibi Hoshō” セントラル警備保障. In Kindai Jūdō 近 代柔道 25/4 (286), 2003a, pp. 87-101

Manabe, Masahiko 真鍋雅彦. “Ryōtokuji Gakuen”了徳寺学園. In Kindai Jūdō 近代柔道 25/6 (288), 2003b, pp. 106-109

Manabe, Masahiko 真鍋雅彦. "Nihon Ēsu Sapōto”日本エースサポート. In Kindai Jūdō 近代柔 道 25/8 (290), 2003c, pp. 100-103 
Manabe, Masahiko 真鍋雅彦. “Nihon Tsūun” 日本通運. In Kindai Jūdō 近代柔道 25/10 (292), 2003d, pp. 100-103

Manabe, Masahiko 真鍋雅彦. “Yamagata Shiyakusho” 山形市役所. In Kindai Jūdō 近代柔道 26/1 (295), 2004a, pp. 93-96

Manabe, Masahiko 真鍋雅彦. “Hariba” はりば. In Kindai Jūdō 近代柔道 26/3 (297), 2004b, pp. 31-34

Manabe, Masahiko 真鍋雅彦. “Yakkusu Kea Sābisu” ヤックスケアサービス. In Kindai Jūdō 近 代柔道 27/8 (314), 2005, pp. 96-99

Manabe, Masahiko 真鍋雅彦. “Aruze Kabushiki Gaisha”アルゼ株式会社. In Kindai Jūdō 近代 柔道 28/4 (322), 2006, pp. 102-105

Mikihouse ミキハウス. "Player list.” Mikihouse Company web site, http://www.mikihouse.co.jp/miki_sports/player, accessed August 2008

Ohno, Akira et al. Sports in Japan. About Japan Series. Tōkyō: Foreign Press Center, 2002

Ōno, Seiji 大野誠治. Asahi Kasei no undōbu. Orinpikku nihon daihyōtachi wo sodateta nobushi shūdan no eikō no kiseki 旭化成の運動部. オリンピック日本代表たちを育てた野武士集 団の栄光の軌跡 [The sports clubs of Asahi Kasei. The glorious traces of a group of feral samurai who formed Japanese representatives in the Olympics]. Tōkyō: Chūkei shuppan, 2000

Onoda, Etsuko 小野田悦子. "Hatsu no shōkintaikai, guranpuri ga sutāto” 初の賞金大会、グラ ンプリがスタート [The first tournament with prize money, start of the Grand Prix Tournaments]. In Kindai Jūdo 近代柔道 23/12 (270), 2001, pp. 10-13

Ōsako, Akinobu 大迫明伸. "Hatsusanka no nihon danshi. Yūshō wa rokuji kiro kyū no Egusa nomi ni owaru” 初参加の日本男子. 優勝は $60 \mathrm{~kg}$ 級の江種のみに終わる [The first participation by the Japanese men's team. Just one win in the 60kg-category by Egusa]. In Kindai Jū dō 近代柔道 24/12 (282), 2002, pp. 26-27

Saeki, Toshio 佐伯年詩雄. Gendai kigyō supōtsuron. Yōroppa kigyō no supōtsu shien chōsa ni motozuku keiei senryaku shigen to shite no katsuyō 現代企業スポーツ論. ヨーロッパ企業 のスポーツ支援調查に基づく経営戦略資源としての活用 [Essay on Japanese corporate sports. Appliance of management strategies based on research to sports promotion in European companies]. Tōkyō: Fumaido shuppan, 2004

Sawano, Masahiko 澤野雅彦. Kigyō supōtsu no eikō to zasetsu 企業スポーツの栄光と挫折 [The brilliance and the breakdown of corporate sports]. Tōkyō: Seikyūsha, 2005

Shibata, Masahiro 柴田真宏. "Rankingusei ya 'kōka' haishi, kokusai jūdō renmei ga shinkiyaku shōnin ランキング制や『効果』廃止、国際柔道連盟が新規約承認 [Acceptance by the International Judo Federation of new implementations such as the ranking system and the abolishment of the smallest point 'kōka' ]. Asahi Shinbun. http://www.asahi.com/sports/spo/TKY200810210348.html, accessed November 2008

Takahashi, Yoshio 高橋義雄. “Supōtsu rōdō shijō” スポーツ労働市場 [The employment market in sports]. In Supōtsu no keizaigaku スポーツの経済学 [The economy of sports], edited by Masaru Ikeda 池田勝 and Shinji Morinō 守能信次. Tōkyō: Kyōrin shoin, 2004, pp. 149-166

Tamaki, Masayuki 玉木正之. Supōtsu kaitai shinsho スポーツ解体新書 [New book on the anatomy of sports]. Tōkyō: Asahi shinbunsha, 2006

Tanakadate, Tetsuhiko 田中館哲彦. “Shin Nihon Seitetsu” 新日本製鉄. In Kindai Jūdō 近代柔 道 22/8 (254), 2000a, pp. 110-113

Tanakadate, Tetsuhiko 田中館哲彦. “Heisei Kanzai” 平成管財. In Kindai Jūdō 近代柔道 22/9 (255), 2000b, pp. 110-113

Tanakadate, Tetsuhiko 田中館哲彦. “Mikihausu”ミキハウス. In Kindai Jūdō 近代柔道 22/12 (258), 2000c, pp. 102-105 
Tanakadate, Tetsuhiko 田中館哲彦. “Tōkyō Shōbōchō” 東京消防庁. In Kindai Jūdō 近代柔道 23/3 (261), 2001a, pp. 104-107

Tanakadate, Tetsuhiko 田中館哲彦. “Daikoro” ダイコロ. In Kindai Jūdō 近代柔道 23/9 (267), 2001b, pp. 118-121

Watanabe, Tamotsu 渡辺保. Gendai supōtsu sangyōron. Supōtsu bijinesu no shiteki tenkai to manejimento wo chüshin ni 現代スポーツ産業論. スポーツビジネスの史的展開とマネジ メントを中心に [Essay on the present sports industry. The historical development and management of sports business in focus.]. Tōkyō: Dōyūkan, 2005

Yamazaki, Toshio 山崎利夫. “Māketingu puroguramu no tenkai” マーケティングプログラムの 展開 [The development of marketing programmes]. In Supōtsu no keieigaku スポーツの経営 学 [The science of management of sports], edited by Masaru Ikeda 池田勝 and Shinji Morinō 守能信次. Tōkyō: Kyōrin shoin, 2004, pp. 84-113

Zennihon Jūdō Renmei 全日本柔道連盟. “Taikai Jōhō” 大会情報 Zennihon Jūdō Renmei [Japanese Judo Federation]. Web site. www.judo.or.jp, accessed September 2008 


\section{GLOSSARY}

\begin{tabular}{|c|c|c|}
\hline Asahi Kasei & 旭化成 & $\begin{array}{l}\text { company involved in materials } \\
\text { science and production of chemi- } \\
\text { cals }\end{array}$ \\
\hline Jieitai Taiiku Gakkō & 自衛隊体育学校 & $\begin{array}{l}\text { Military Physical Education } \\
\text { School }\end{array}$ \\
\hline jitsugyō jū & 実業柔道 & $\begin{array}{l}\text { corporate judo; company sports } \\
\text { focusing on Japanese judo }\end{array}$ \\
\hline $\begin{array}{l}\text { jūdō mo shigoto mo isshō- } \\
\text { kenmei gata }\end{array}$ & 柔道も仕事も一生懸命型 & $\begin{array}{l}\text { working hard in both judo and } \\
\text { work; term describing one type } \\
\text { of corporate athlete in judo in } \\
\text { Japan; corporate athlete who } \\
\text { works full-time and practises } \\
\text { judo every day }\end{array}$ \\
\hline jūdō yūsen gata & 柔道優先型 & $\begin{array}{l}\text { priority to judo; term describing } \\
\text { one type of corporate athlete in } \\
\text { judo in Japan; corporate athlete } \\
\text { who does not have to work in the } \\
\text { company, only practise and } \\
\text { compete }\end{array}$ \\
\hline $\begin{array}{l}\text { jūdō yūsen sukoshi shigoto } \\
\text { gata }\end{array}$ & 柔道優先少し仕事型 & $\begin{array}{l}\text { judo taking precedence over } \\
\text { work; term describing one type of } \\
\text { corporate athlete in judo in Japan; } \\
\text { corporate athlete who has to work } \\
\text { several days a week besides } \\
\text { practice and competition }\end{array}$ \\
\hline kanmuri taikai & 冠大会 & $\begin{array}{l}\text { title-sponsored events or 'crown' } \\
\text { events; sporting events, champi- } \\
\text { onships or competitions which } \\
\text { have the name of the main spon- } \\
\text { sor or the name of a sponsor's } \\
\text { product in the title of the event }\end{array}$ \\
\hline keiyaku senshu & 契約選手 & $\begin{array}{l}\text { contract athlete in corporate } \\
\text { sports; not regularly employed in } \\
\text { the company but under contract } \\
\text { to the company; a sponsor- } \\
\text { athlete relationship }\end{array}$ \\
\hline Keiyō Gasu & 京葉ガス & $\begin{array}{l}\text { supply company for gas and } \\
\text { electric energy }\end{array}$ \\
\hline Kindai Jūudō & 近代柔道 & monthly judo magazine in Japan \\
\hline Kindai Jūdō Cup & 近代柔道杯 & $\begin{array}{l}\text { national championships in judo } \\
\text { for junior high school students in } \\
\text { Japan }\end{array}$ \\
\hline Komatsu & & $\begin{array}{l}\text { company producing construction } \\
\text { machinery }\end{array}$ \\
\hline Mikihouse & ハウス & $\begin{array}{l}\text { company producing children's } \\
\text { clothes }\end{array}$ \\
\hline
\end{tabular}


puro keiyaku senshu

Ryōtokuji Gakuen

Saeki Toshio

seishain

senshu shain

shain senshu

shakai kōken

shigoto yūsen sokosoko jūdō

gata
プロ契約選手

了徳寺学園

佐伯年詩雄

正社員

選手社員

社員選手

社会貢献

仕事優先そこそこ柔道型 professional contract athlete in corporate sports in Japan; athlete who has a contract with the company as a professional athlete without work duties vocational school for sports medicine as a profession born 1942, Japanese sports scientist (sport sociology); publications on sport sociology, sports events, corporate sports, etc. ordinary employee; in the case of corporate sport in Japan ordinarily employed corporate athlete; opposite of the contract athlete and sub-divided between senshu shain and shain senshu sports given priority over work; term indicating the form of employment of a corporate athlete; corporate athlete who is hired as an ordinary employee but is allowed to practise all day or at least the whole afternoon work given priority over sports; term indicating the form of employment of a corporate athlete; corporate athlete whose training time is not included in their work time, so this kind of athlete practises after their full-time work duties social commitment or service; namely, to do something in favour of a region and its inhabitants

priority to work, combined sometimes with judo; term describing one type of corporate athlete in judo in Japan; corporate athlete who for preference works but also practises judo two or three times a week 
shigoto yūsen sukoshi jūdo gata

Shin Nihon Seitetsu (Shin Nittetsu)

shokuba supōtsu

shokutaku senshu

Taishō jidai

Takita Seiichiro

Tamaki Masayuki

Tani Ryōko

Watanabe Tamotsu
仕事優先少し柔道型

新日本製鉄（新日鉄）

職場スポーツ

嘱託選手

大正時代

滝田誠一郎

玉木正之

谷亮子

渡辺保 priority to work with some judo; term describing one type of corporate athlete in judo in Japan; corporate athlete whose main duty is work but who also practises and sometimes takes part in competitions

Japan's biggest steel production company

workplace sports; sporting activities in companies to support employees' health and to strengthen a sense of community and solidarity among them limited contract athlete in corporate sports in Japan; corporate athlete who has a fixed-term employment contract with the company

Taishō Period (1912-1926) born 1955, Japanese non-fiction writer and journalist; publications on sports business, economics, employment, etc.

born 1952, Japanese author, sports writer and music critic; publications on sports, music, etc.

born 1975, Japanese judo player, $48 \mathrm{~kg}$ category; five-time Olympic medallist and seven-time World Champion born 1948, Japanese economist; publications on sports business and management, small and medium-sized enterprises, etc. 